\title{
Paraperlucidibaca baekdonensis gen. nov., sp. nov., isolated from seawater
}

\author{
Correspondence \\ Jung-Hoon Yoon \\ jhyoon@kribb.re.kr
}

\author{
Ki-Hoon Oh, Soo-Young Lee, Mi-Hwa Lee, Tae-Kwang Oh \\ and Jung-Hoon Yoon
}

\author{
Korea Research Institute of Bioscience and Biotechnology (KRIBB), PO Box 115, Yusong, \\ Taejon, Republic of Korea
}

The family Moraxellaceae belongs to the class Gammaproteobacteria and was first proposed by Rossau et al. (1991). The family initially consisted of the genera Moraxella (Lwoff, 1939), Acinetobacter (Brisou \& Prévot, 1954) and Psychrobacter (Juni \& Heym, 1986). Three other genera of the family were subsequently described, namely Enhydrobacter (Staley et al., 1987), Alkanindiges (Bogan et al., 2003) and Perlucidibaca (Song et al., 2008). The genus Perlucidibaca was distinguished from other members of the family Moraxellaceae on the basis of high DNA G $+\mathrm{C}$ content and differences in fatty acid compositions and several phenotypic properties, and was proposed based on the description of a single recognized species, Perlucidibaca piscinae (Song et al., 2008). In this study, we describe a novel bacterial strain, designated RL-2 ${ }^{\mathrm{T}}$, which was isolated from seawater obtained from Baekdo Harbor, East Sea, Korea. Comparative 16S rRNA gene sequence analysis indicated that strain RL- $2^{\mathrm{T}}$ is phylogenetically most closely affiliated to the genus Perlucidibaca and several uncultured bacterial clones. The aim of the present work was to determine the exact taxonomic position of strain $\mathrm{RL}-2^{\mathrm{T}}$ by using a polyphasic approach.

Strain $\mathrm{RL}-2^{\mathrm{T}}$ was isolated by using standard dilution plating on R2A agar (Difco) at $20{ }^{\circ} \mathrm{C}$. Perlucidibaca piscinae

The GenBank/EMBL/DDBJ accession number for the 16S rRNA gene sequence of strain RL-2 ${ }^{T}$ is GU731671.
IMCC $1704^{\mathrm{T}}$, which was used as a reference strain for phenotypic characterization and fatty acid analysis, was obtained from the original authors and was cultivated routinely at $30{ }^{\circ} \mathrm{C}$ on $\mathrm{R} 2 \mathrm{~A}$ agar. Morphological, physiological and biochemical characteristics of strain RL-2 ${ }^{\mathrm{T}}$ were investigated by using routine cultivation at $20{ }^{\circ} \mathrm{C}$ on $\mathrm{R} 2 \mathrm{~A}$ agar. Cell morphology was examined by light microscopy (E600; Nikon) and transmission electron microscopy. Flagellation was determined by using a Philips CM-20 transmission electron microscope with cells incubated for 5 days at $20{ }^{\circ} \mathrm{C}$; cells were negatively stained with $1 \%$ $(\mathrm{w} / \mathrm{v})$ phosphotungstic acid and the grids were examined after being air-dried. The Gram reaction was determined by using the bioMérieux Gram stain kit according to the manufacturer's instructions. Growth under anaerobic conditions was determined after incubation in a Forma anaerobic chamber on R2A agar and on R2A agar supplemented with potassium nitrate $(0.1 \%$, w/v), both of which had been prepared anaerobically under nitrogen atmosphere. Growth at 4, 10, 15, 20, 25, 30 and $37{ }^{\circ} \mathrm{C}$ was determined on R2A agar. Growth with $0-7.0 \%$ (w/v) $\mathrm{NaCl}$ (increments of $1.0 \%$ ) was investigated on R2A agar. Growth in the absence of $\mathrm{NaCl}$ was also investigated in trypticase soy broth prepared according to the formula of the Difco medium except that $\mathrm{NaCl}$ was excluded. The optimal $\mathrm{pH}$ and $\mathrm{pH}$ range for growth were determined in R2A broth prepared according to the formula of the Difco 
medium except that agar was excluded. The medium was adjusted to $\mathrm{pH} 4.5-10.5$ (intervals of $0.5 \mathrm{pH}$ units) by using sodium acetate/acetic acid and $\mathrm{Na}_{2} \mathrm{CO}_{3}$ buffers. Catalase and oxidase activities were tested as described by Cowan \& Steel (1965). Nitrate reduction and hydrolysis of aesculin, gelatin and urea were tested as described by Lányí (1987). Hydrolysis of casein, hypoxanthine, starch, tyrosine, xanthine, and Tweens 20, 40, 60 and 80 was tested on R2A agar by using the substrate concentrations described by Cowan \& Steel (1965). Utilization of various substrates was tested as described by Baumann \& Baumann (1981), by using supplementation with $2 \%(\mathrm{v} / \mathrm{v})$ Hutner's mineral salts solution (Cohen-Bazire et al., 1957) and $1 \%(\mathrm{v} / \mathrm{v})$ vitamin solution (Staley, 1968). The carbon sources were added at a concentration of $0.2 \%(\mathrm{w} / \mathrm{v})$ after sterilization by filtration. Enzyme activities were determined by using the API ZYM system (bioMérieux).

Cell biomass of strain RL-2 ${ }^{\mathrm{T}}$ for DNA extraction and for isoprenoid quinone analysis was harvested from cultures grown for 9 days on R2A agar at $20{ }^{\circ} \mathrm{C}$. Chromosomal DNA was extracted and purified according to the method described by Yoon et al. (1996), with the exception that RNase T1 was used in combination with RNase A to minimize contamination of RNA. The $16 \mathrm{~S}$ rRNA gene was amplified by PCR using two universal primers ( $5^{\prime}$ GAGTTTGATCCTGGCTCAG-3' and 5'-AGAAAGGAGGTGATCCAGCC- $3^{\prime}$ ) as described previously (Yoon et al., 1998) and was purified by using a QIAquick purification kit (Qiagen). Sequencing of the amplified 16S rRNA gene and phylogenetic analysis were performed according to the methods of Yoon et al. (2003). The DNA G + C content was determined by the method of Tamaoka \& Komagata (1984) with the modification that DNA was hydrolysed and the resultant nucleotides were analysed by reversedphase HPLC. Isoprenoid quinones were extracted according to the method of Komagata \& Suzuki (1987) and were analysed by using reversed-phase HPLC and a YMC ODS-A $(250 \times 4.6 \mathrm{~mm})$ column. For cellular fatty acid analysis, cell mass of strain RL-2 ${ }^{\mathrm{T}}$ and Perlucidibaca piscinae IMCC $1704^{\mathrm{T}}$ was harvested from R2A agar plates after incubation for 6 days at $20{ }^{\circ} \mathrm{C}$. Fatty acids were extracted and fatty acid methyl esters were prepared according to the standard protocol of the MIDI/Hewlett Packard Microbial Identification System (Sasser, 1990).

Morphological, cultural, physiological and biochemical characteristics of strain RL- $2^{\mathrm{T}}$ are given in the genus and species descriptions below and in Table 1. The almostcomplete 16S rRNA gene sequence of strain RL-2 ${ }^{\mathrm{T}}$ determined in this study comprised $1460 \mathrm{nt}$, representing approximately $96 \%$ of the Escherichia coli $16 \mathrm{~S}$ rRNA gene sequence. In the phylogenetic trees reconstructed with the neighbour-joining, maximum-likelihood and maximumparsimony algorithms, strain RL-2 ${ }^{\mathrm{T}}$ fell within a cluster comprising Perlucidibaca piscinae $\mathrm{IMCC} 1704^{\mathrm{T}}$ and various uncultured and unidentified gammaproteobacteria (Fig. 1). Strain RL-2 ${ }^{\mathrm{T}}$ exhibited highest $16 \mathrm{~S}$ rRNA gene sequence

Table 1. Differential phenotypic characteristics between strain RL-2 ${ }^{\top}$ and Perlucidibaca piscinae IMCC $1704^{\top}$

Data for Perlucidibaca piscinae IMCC1704 ${ }^{\mathrm{T}}$ are from Song et al. (2008) and this study. W, Weakly positive reaction. The two strains are positive for activity of oxidase, esterase (C4) and esterase lipase (C8), but negative for catalase, hydrolysis of casein $\dagger$, gelatin, hypoxanthine $\dagger$, xanthine $\dagger$, L-tyrosine $\dagger$ and urea, and activity of lipase (C14), valine arylamidase, cystine arylamidase, trypsin, $\alpha$-chymotrypsin, acid phosphatase, naphthol-ASBI-phosphohydrolase, $N$-acetyl- $\beta$-glucosaminidase, $\alpha$-galactosidase, $\beta$-galactosidase, $\beta$-glucuronidase, $\alpha$-glucosidase, $\beta$-glucosidase, $\alpha$-mannosidase and $\alpha$-fucosidase.

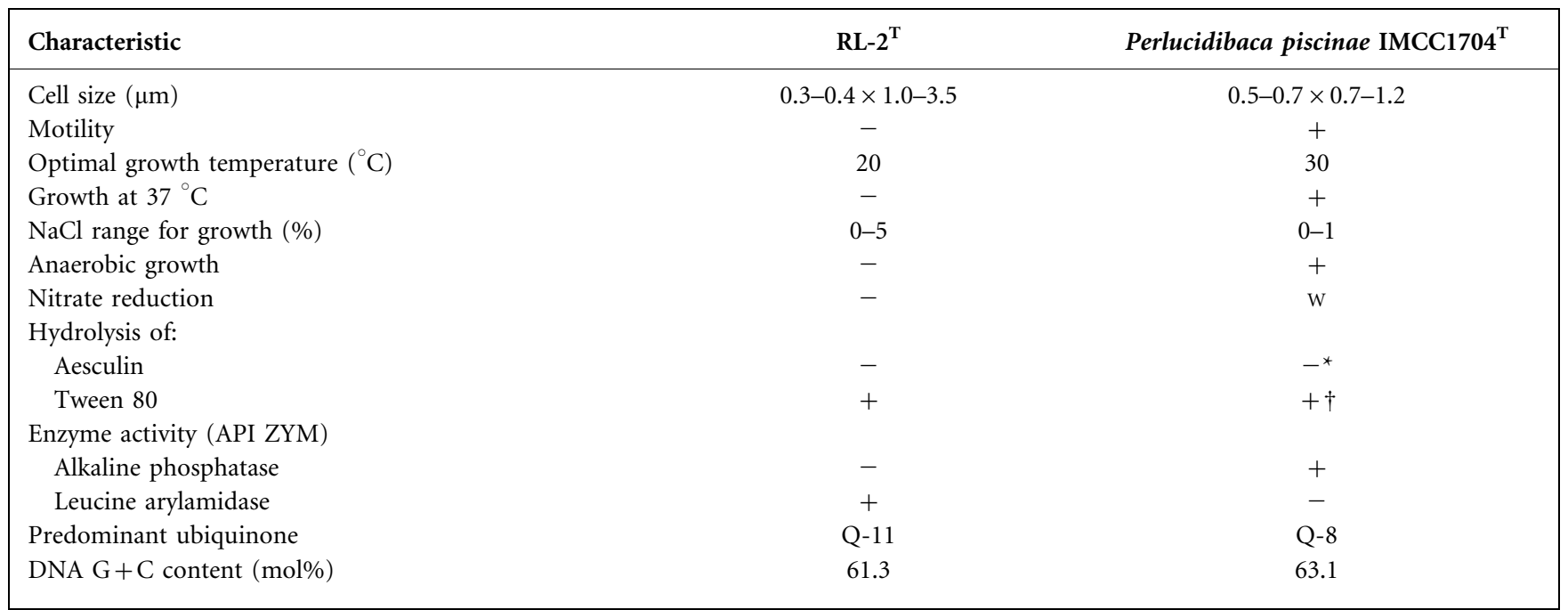

${ }^{\star}$ Weakly positive in Song et al. (2008).

$\dagger$ Data for P. piscinae IMCC $1704^{\mathrm{T}}$ are from this study. 


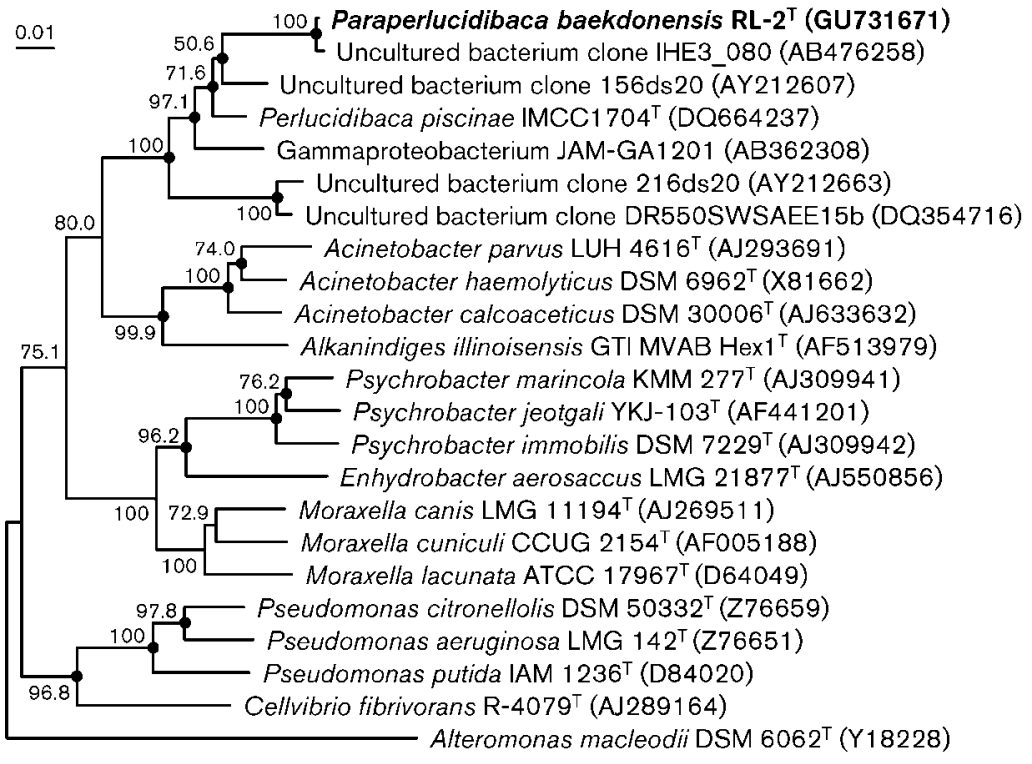

Fig. 1. Neighbour-joining phylogenetic tree based on 16S rRNA gene sequences showing the positions of strain $\mathrm{RL}-2^{\top}$, uncultured bacterial clones and some other related taxa. Bootstrap values (expressed as percentages of 1000 replications) of $>50 \%$ are shown at branch points. Filled circles indicate that the corresponding nodes were also recovered in the trees generated with the maximum-likelihood and maximum-parsimony algorithms. Alteromonas macleodii DSM $6062^{\top}$ was used as the outgroup. Bar, 0.01 substitutions per nucleotide position. similarity $(99.7 \%)$ to uncultured bacterial clone IHE3_080 and $93.7-96.4 \%$ to three other uncultured bacterial clones belonging to the same cluster. Strain RL-2 ${ }^{\mathrm{T}}$ exhibited $16 \mathrm{~S}$ rRNA gene sequence similarity values of 96.1 and $94.5 \%$ to Perlucidibaca piscinae $\mathrm{IMCC} 1704^{\mathrm{T}}$ and gammaproteobacterium JAM-GA1201, respectively, and less than $91.5 \%$ to the type strains of other species used in the phylogenetic analysis. The predominant isoprenoid quinone detected in strain RL-2 ${ }^{\mathrm{T}}$ was ubiquinone-11 (Q-11). The cellular fatty acid profile of strain RL-2 ${ }^{\mathrm{T}}$ is shown in Table 2, together with that of Perlucidibaca piscinae IMCC $1704^{\mathrm{T}}$. The major fatty acids ( $>10 \%$ of the total) found in strain RL-2 ${ }^{\mathrm{T}}$ were $\mathrm{C}_{16: 1} \omega 7 c$ and/or iso- $\mathrm{C}_{15: 0} \quad 2-\mathrm{OH} \quad(31.1 \%), \mathrm{C}_{18: 1} \omega 7 c$ $(17.3 \%), \mathrm{C}_{16: 0}(12.0 \%)$ and $\mathrm{C}_{12: 0} 3-\mathrm{OH}(10.0 \%)$. The DNA G + C content of strain RL-2 ${ }^{\mathrm{T}}$ was $61.3 \mathrm{~mol} \%$.

In this study, strain RL-2 ${ }^{\mathrm{T}}$, Perlucidibaca piscinae IMCC $1704^{\mathrm{T}}$, an unidentified gammaproteobacterium and several uncultured bacterial clones were found to form a phylogenetic cluster that is independent of all other members of the class Gammaproteobacteria (Fig. 1). The fatty acid profile of strain RL-2 ${ }^{\mathrm{T}}$ was essentially similar to that of Perlucidibaca piscinae $\mathrm{IMCC} 1704^{\mathrm{T}}$, even though there were differences in the proportions of some components (Table 2). However, the predominant ubiquinone (Q-11) of strain RL-2 ${ }^{\mathrm{T}}$ was different from those of other members of the family Moraxellaceae as well as from Perlucidibaca piscinae IMCC $1704^{\mathrm{T}}$, which contain Q-8 or Q-9 as the predominant ubiquinone (Song et al., 2008). Strain RL-2 ${ }^{\mathrm{T}}$ could also be differentiated from Perlucidibaca piscinae IMCC $1704^{\mathrm{T}}$ based on differences in several phenotypic properties, including motility, optimal growth temperature, $\mathrm{NaCl}$ tolerance, anaerobic growth and nitrate reduction, as shown in Table 1. The phylogenetic data and differential chemotaxonomic and phenotypic properties suggest that strain RL-2 ${ }^{\mathrm{T}}$ represents a novel species of a new genus within the family Moraxellaceae, class Gammaproteobacteria, for which the name Paraperlucidibaca baekdonensis gen. nov., sp. nov. is proposed.

\section{Description of Paraperlucidibaca gen. nov.}

Paraperlucidibaca (Pa.ra.per.lu.ci.di.ba'ca. Gr. prep. para like, beside; N.L. fem. n. Perlucidibaca a bacterial generic name; N.L. fem. n. Paraperlucidibaca resembling Perlucidibaca).

Cells are Gram-stain-negative, non-motile and rod-shaped. Strictly aerobic. Catalase-negative and oxidase-positive. Nitrate is not reduced to nitrite. The predominant ubiquinone is Q-11. The major fatty acids ( $>10 \%$ of the total) are $\mathrm{C}_{16: 1} \omega 7 c$ and/or iso- $\mathrm{C}_{15: 0} 2-\mathrm{OH}, \mathrm{C}_{18: 1} \omega 7 c, \mathrm{C}_{16: 0}$ and $\mathrm{C}_{12: 0}$ 3-OH. The type species is Paraperlucidibaca baekdonensis.

\section{Description of Paraperlucidibaca baekdonensis sp. nov.}

Paraperlucidibaca baekdonensis (baek.do.nen'sis. N.L. fam. adj. baekdonensis of Baekdo, from where the type strain was isolated).

Exhibits the following properties in addition to those given in the genus description. Cells are $0.3-0.4 \mu \mathrm{m}$ wide and 1.0$3.5 \mu \mathrm{m}$ long. Colonies are circular, raised, smooth, semitransparent, yellowish white and $0.5-1.0 \mathrm{~mm}$ in diameter after incubation on R2A agar at $20{ }^{\circ} \mathrm{C}$ for 7 days. Optimal growth is at $20{ }^{\circ} \mathrm{C}$; growth occurs at $10-30{ }^{\circ} \mathrm{C}$ but not at 4 or $37^{\circ} \mathrm{C}$. Optimal growth is at $\mathrm{pH} 7.5-8.0$; growth occurs at $\mathrm{pH} 6.0$ but not at $\mathrm{pH}$ 5.5. Growth occurs in the presence of $0-5 \%(\mathrm{w} / \mathrm{v}) \mathrm{NaCl}$ with optimal growth in the absence of $\mathrm{NaCl}$. Hydrolyses Tweens 20, 40, 60 and 80, but not aesculin, casein, gelatin, hypoxanthine, starch, L-tyrosine, xanthine or urea. Utilizes D-glucose, D-fructose, maltose, D-mannose, sucrose, trehalose, acetate, benzoate and pyruvate as carbon and energy sources, but not L-arabinose, cellobiose, D-galactose, D-xylose, citrate, L-malate, formate, salicin, 
Table 2. Cellular fatty acid compositions (\%) of strain $\mathrm{RL}-2^{\top}$ and Perlucidibaca piscinae IMCC $1704^{\top}$

Strains: 1, RL-2 ${ }^{\mathrm{T}}$ (grown for 6 days on R2A agar at $20{ }^{\circ} \mathrm{C}$ ); 2 , Perlucidibaca piscinae IMCC $1704^{\mathrm{T}}$ (6 days on R2A agar at $20{ }^{\circ} \mathrm{C}$; data from this study); 3, Perlucidibaca piscinae IMCC1704 ${ }^{\mathrm{T}}$ (3 days on R2A agar at $30{ }^{\circ} \mathrm{C}$; data from Song et al., 2008). Fatty acids that represented $<0.5 \%$ in all columns were omitted. tr, Trace $(<0.5 \%)$. - , Not detected.

\begin{tabular}{|lccc|}
\hline Fatty acid & $\mathbf{1}$ & $\mathbf{2}$ & $\mathbf{3}$ \\
\hline Straight-chain & & & \\
$\mathrm{C}_{10: 0}$ & 4.6 & 4.2 & 3.4 \\
$\mathrm{C}_{11: 0}$ & - & 0.7 & - \\
$\mathrm{C}_{12: 0}$ & 3.1 & 10.2 & 10.1 \\
$\mathrm{C}_{14: 0}$ & 4.6 & 3.7 & 3.1 \\
$\mathrm{C}_{15: 0}$ & $\operatorname{tr}$ & 0.6 & $\operatorname{tr}$ \\
$\mathrm{C}_{16: 0}$ & 12.0 & 12.9 & 5.8 \\
$\mathrm{C}_{17: 0}$ & - & 1.1 & 0.7 \\
$\mathrm{C}_{18: 0}$ & 5.7 & 2.7 & 2.7 \\
Branched & & & \\
iso-C $16: 0$ & - & 1.0 & - \\
iso-C $17: 0$ & - & 0.6 & 0.9 \\
Unsaturated & & & \\
$\mathrm{C}_{17: 1} \omega 8 c$ & $\operatorname{tr}$ & 3.7 & 5.5 \\
$\mathrm{C}_{18: 1} \omega 7 c$ & 17.3 & 14.3 & 12.8 \\
$\mathrm{C}_{18: 1} \omega 9 c$ & 2.6 & 4.6 & 9.2 \\
Hydroxy & & & \\
$\mathrm{C}_{10: 0} 2-\mathrm{OH}$ & 1.8 & $\operatorname{tr}$ & 1.5 \\
$\mathrm{C}_{10: 0} 3-\mathrm{OH}$ & 1.7 & $\operatorname{tr}$ & 0.6 \\
$\mathrm{C}_{12: 0} 3-\mathrm{OH}$ & 10.0 & 8.6 & 12.3 \\
11 methyl $\mathrm{C}_{18: 1} \omega 7 c$ & 1.4 & 1.3 & - \\
Summed feature $3^{*}$ & 31.1 & 24.6 & 21.2 \\
Unknown $^{*}$ & & & \\
$\mathrm{ECL}_{11.799}$ & 1.4 & - & - \\
ECL 12.484 & 0.7 & 0.7 & 1.4 \\
\hline
\end{tabular}

${ }^{*}$ Summed features represent groups of two or three fatty acids which could not be separated by GLC with the MIDI system. Summed feature 3 comprised $\mathrm{C}_{16: 1} \omega 7 c$ and/or iso- $\mathrm{C}_{15: 0} 2-\mathrm{OH}$.

$\dagger E C L$, equivalent chain-length.

succinate or L-glutamate. In assays with the API ZYM system, positive for activities of esterase (C4), esterase lipase (C8) and leucine arylamidase, but negative for alkaline phosphatase, lipase (C14), valine arylamidase, cystine arylamidase, trypsin, $\alpha$-chymotrypsin, acid phosphatase, naphthol-AS-BI-phosphohydrolase, $N$-acetyl- $\beta$-glucosaminidase, $\alpha$-galactosidase, $\beta$-galactosidase, $\beta$-glucuronidase, $\alpha$-glucosidase, $\beta$-glucosidase, $\alpha$-mannosidase and $\alpha$-fucosidase. The DNA G $+\mathrm{C}$ content of the type strain is $61.3 \mathrm{~mol} \%$.

The type strain, RL-2 ${ }^{\mathrm{T}}\left(=\right.$ KCTC $23145^{\mathrm{T}}=$ CCUG $\left.59307^{\mathrm{T}}\right)$, was isolated from seawater of Baekdo Harbor in the East Sea, Korea.

\section{Acknowledgements}

This work was supported by the 21C Frontier Program of Microbial Genomics and Applications (grant MG05-0401-2-0) and the Support and Application Project of Biological Resources (grant M1050805 0004-06N0805-00410) from the Ministry of Education, Science and Technology (MEST) of the Republic of Korea.

\section{References}

Baumann, P. \& Baumann, L. (1981). The marine gram-negative eubacteria: genera Photobacterium, Beneckea, Alteromonas, Pseudomonas and Alcaligenes. In The Prokaryotes, vol. 2, pp. 1302-1331. Edited by M. P. Starr, H. Stolp, H. G. Trüper, A. Balows \& H. Schleger. Berlin: Springer.

Bogan, B. W., Sullivan, W. R., Kayser, K. J., Derr, K. D., Aldrich, H. C. \& Paterek, J. R. (2003). Alkanindiges illinoisensis gen. nov., sp. nov., an obligately hydrocarbonoclastic, aerobic squalane-degrading bacterium isolated from oilfield soils. Int J Syst Evol Microbiol 53, 1389-1395.

Brisou, J. \& Prévot, A. R. (1954). [Studies on bacterial taxonomy. X. The revision of species under Acromobacter group]. Ann Inst Pasteur (Paris) 86, 722-728 (in French).

Cohen-Bazire, G., Sistrom, W. R. \& Stanier, R. Y. (1957). Kinetic studies of pigment synthesis by nonsulfur purple bacteria. J Cell Comp Physiol 49, 25-68.

Cowan, S. T. \& Steel, K. J. (1965). Manual for the Identification of Medical Bacteria. London: Cambridge University Press.

Juni, E. \& Heym, G. A. (1986). Psychrobacter immobilis gen. nov., sp. nov.: genospecies composed of Gram-negative, aerobic, oxidasepositive coccobacilli. Int J Syst Bacteriol 36, 388-391.

Komagata, K. \& Suzuki, K. (1987). Lipid and cell-wall analysis in bacterial systematics. Methods Microbiol 19, 161-207.

Lányí, B. (1987). Classical and rapid identification methods for medically important bacteria. Methods Microbiol 19, 1-67.

Lwoff, A. (1939). Révision et démembrement des Hemophilae, le genre Moraxella nov. gen. Ann Inst Pasteur (Paris) 62, 168-176 (in French).

Rossau, R., Van Landschoot, A., Gillis, M. \& De Ley, J. (1991). Taxonomy of Moraxellaceae fam. nov., a new bacterial family to accommodate the genera Moraxella, Acinetobacter, and Psychrobacter and related organisms. Int J Syst Bacteriol 41, 310-319.

Sasser, M. (1990). Identification of bacteria by gas chromatography of cellular fatty acids, MIDI Technical Note 101. Newark, DE: MIDI.

Song, J., Choo, Y.-J. \& Cho, J.-C. (2008). Perlucidibaca piscinae gen. nov., sp. nov., a freshwater bacterium belonging to the family Moraxellaceae. Int J Syst Evol Microbiol 58, 97-102.

Staley, J. T. (1968). Prosthecomicrobium and Ancalomicrobium: new prosthecate freshwater bacteria. J Bacteriol 95, 1921-1942.

Staley, J. T., Irgens, R. L. \& Brenner, D. J. (1987). Enhydrobacter aerosaccus gen. nov., sp. nov., a gas-vacuolated, facultatively anaerobic, heterotrophic rod. Int J Syst Bacteriol 37, 289-291.

Tamaoka, J. \& Komagata, K. (1984). Determination of DNA base composition by reversed-phase high-performance liquid chromatography. FEMS Microbiol Lett 25, 125-128.

Yoon, J.-H., Kim, H., Kim, S.-B., Kim, H.-J., Kim, W. Y., Lee, S. T., Goodfellow, M. \& Park, Y.-H. (1996). Identification of Saccharomonospora strains by the use of genomic DNA fragments and rRNA gene probes. Int J Syst Bacteriol 46, 502-505.

Yoon, J.-H., Lee, S. T. \& Park, Y.-H. (1998). Inter- and intraspecific phylogenetic analysis of the genus Nocardioides and related taxa based on 16S rDNA sequences. Int J Syst Bacteriol 48, 187-194.

Yoon, J.-H., Kim, I.-G., Shin, D.-Y., Kang, K. H. \& Park, Y.-H. (2003). Microbulbifer salipaludis sp. nov., a moderate halophile isolated from a Korean salt marsh. Int J Syst Evol Microbiol 53, 53-57. 